\title{
Killer Whale Predation on a Leatherback Turtle in the Northeast Pacific ${ }^{1}$
}

\author{
Robert L. Pitman ${ }^{2,3}$ and Peter H. Dutton ${ }^{2}$
}

\begin{abstract}
In November 2001, we observed a herd of killer whales (Orcinus orca) preying upon a leatherback turtle (Dermochelys coriacea) off the coast of California. Here we provide details of the event and speculate that oceanic killer whales may have less specialized diets than nearshore populations. We also suggest that killer whale predation should be considered a factor in the recovery of this critically endangered sea turtle.
\end{abstract}

On 3 November 2001, while conducting a marine mammal survey off the west coast of the United States, we observed a herd of killer whales, Orcinus orca (Linnaeus, 1758), feeding on a leatherback turtle, Dermochelys coriacea (Linnaeus, 1758), that they had apparently just killed. The event took place at $40^{\circ} 53^{\prime} \mathrm{N}, 128^{\circ} 34^{\prime} \mathrm{W}$, approximately $350 \mathrm{~km}$ almost due west of Cape Mendocino, California, in water $3,178 \mathrm{~m}$ deep; the surface water temperature was $16.2^{\circ} \mathrm{C}$ and the initial time of sighting was 1210 Local Mean Time.

When we initially sighted the whales they were milling and diving in a large slick on the surface of the water. We assumed that a kill had just taken place because the whales were still feeding, and both the slick (presumably animal fat) and a gathering flock of feeding birds increased throughout our observation period of some $20 \mathrm{~min}$. The bird flock eventually contained 171 birds of 12 species.

We estimated that there were seven killer whales in the herd. As we approached, most of the herd traveled away from the site but two individuals remained behind: an adult male and a smaller female or subadult male.

\footnotetext{
${ }^{1}$ Manuscript accepted 20 October 2003.

${ }^{2}$ National Marine Fisheries Service, Southwest Fisheries Science Center, 8604 La Jolla Shores Drive, La Jolla, California 92037.

${ }^{3}$ E-mail: robert.pitman@noaa.gov.
}

Pacific Science (2004), vol. 58, no. 3:497-498

(C) 2004 by University of Hawai'i Press

All rights reserved
The two whales were surfacing and diving synchronously within the slick. On one occasion, while the whales were submerged, several albatrosses converged to feed on a large pale object that floated to the surface within $10 \mathrm{~m}$ of where the whales had just dived. We put a launch in the water and retrieved what turned out to be the posterior section of a large leatherback carapace. Although most of the flesh had been removed from the inside and around the edges, the bits still attached were pink and very fresh. On the trailing edge of the carapace there was a series of fresh, widely spaced (ca. $2.5 \mathrm{~cm}$ ) tooth marks made by one of the killer whales. Because the turtle had obviously died very recently and the killer whales were feeding on it, we infer that this was a predation event.

The piece of carapace we recovered measured $104 \mathrm{~cm}$ from the posterior tip to the leading edge of the middorsal line. Comparing it with photos of adult leatherback turtles, we estimated that it comprised approximately two-thirds of the total carapace; from that we concluded that the curved carapace length (CCL) of the intact animal had been about $150 \mathrm{~cm}$. The CCL of mature (i.e., nesting) female leatherbacks averages 134-167 cm (Zug and Parnham 1996), indicating that the turtle was an adult.

We analyzed mitochondrial DNA from the specimen using methods described in Dutton et al. (1999) and determined that this animal was of western Pacific origin. This is consistent with recent findings that most leatherbacks encountered in fisheries in the North Pacific or that strand along the west 
coast of the United States are from western Pacific nesting populations, including Irian Jaya in Indonesia, Papua New Guinea, and the Solomon Islands (Dutton et al. 2000).

There are two previous published reports of killer whales preying upon leatherback turtles. Caldwell and Caldwell (1969) reported that three whales killed from a group of six by a commercial fishing boat in the Caribbean all had remains of a single leatherback turtle in their stomachs. Of interest, the group size of these killer whales was similar to that reported here (six versus seven), and the whales had apparently also shared their prey. Sarti et al. (1994) observed an apparent attack by a lone male killer whale near Michoacán, off the Pacific coast of Mexico. The whale was milling for approximately $2 \mathrm{hr}$ near a slick on the water where the remains of a gravid female leatherback turtle were recovered. As in our sighting, the whale was apparently feeding on a carcass some distance below the surface and it also seemed interested in consuming only certain parts of the turtle while discarding others (e.g., female reproductive organs).

Studies to date on killer whale feeding habits have found a high degree of dietary specialization, at least among populations in neritic habitats. For example, in the Pacific Northwest area of the United States and Canada, "resident" killer whales feed largely on fish (mainly salmon), but sympatric populations of "transient" killer whales prey almost entirely on marine mammals (see review in Baird 2000). In New Zealand, nearshore populations of killer whales feed mainly on elasmobranchs (sharks and rays) (Visser 1999, Visser et al. 2000). In offshore waters of the North Pacific there may not be sufficient concentrations of any one kind of prey type (especially endangered leatherback turtles) to allow for this degree of specialization, and pelagic populations of killer whales may, in general, prove to be more omnivorous than neritic populations. However, because the leatherback turtle is critically endangered in the Pacific (Spotila et al. 2000), even opportunistic predation by killer whales should be considered a factor in recovery efforts for this species.
We thank G. Balazs for his review comments.

\section{Literature Cited}

Baird, R. W. 2000. The killer whale: Foraging specializations and group hunting. Pages 127-153 in J. Mann, R. C. Connor, P. L. Tyack, and H. Whitehead, eds. Cetacean societies. University of Chicago Press, Chicago.

Caldwell, D. K., and M. C. Caldwell. 1969. Addition of the leatherback sea turtle to the known prey of the killer whale, Orcinus orca. J. Mammal. 50:636.

Dutton, P. H., B. W. Bowen, D. W. Owens, A. Barragan, and S. K. Davis. 1999. Global phylogeography of the leatherback turtle, Dermochelys coriacea: Shallow phylogenetic history in an ancient organismal lineage. J. Zool. 248:397-409.

Dutton, P. H., A. Frey, R. LeRoux, and G. Balazs. 2000. Molecular ecology of leatherbacks in the Pacific. Pages 248-253 in N. Pilcher and G. Ismail, eds. Sea turtles of the Indo-Pacific: Research, management and conservation. ASEAN Academic Press, London.

Sarti M., L., L. Flores O., and A. Aguayo L. 1994. Evidence of predation of killer whale (Orcinus orca) on a leatherback sea turtle (Dermochelys coriacea) in Michoacan, Mexico. Rev. Invest. Cient. 2:23-26.

Spotila, J. R., R. D. Reina, A. C. Steyermark, P. T. Plotkin, and F. V. Paladino. 2000. Pacific leatherback turtles face extinction. Nature (Lond.) 405:529-530.

Visser, I. 1999. Benthic foraging on stingrays by killer whales (Orcinus orca) in New Zealand waters. Mar. Mamm. Sci. 15:220227.

Visser, I. N., J. Berghan, R. van Meurs, and D. Fertl. 2000. Killer whale (Orcinus orca) predation on a shortfin mako shark (Isurus oxyrinchus) in New Zealand waters. Aquat. Mamm. 26:229-231.

Zug, G. R., and J. F. Parham. 1996. Age and growth in leatherback turtles, Dermochelys coriacea (Testudines: Dermochelyidae): A skeletochronological analysis. Chelon. Conserv. Biol. 2:244-249. 